\title{
Electron Microscopy of Human Pituitary Adenomas. Correlation of the Secretory Granules with the Experimentally and Clinically Evaluated Hormone Synthesis Function of the Adenoma Tissue
}

\author{
Tsuneo SHIMIzU, Yoichi IsHIDA* and Fumikazu TAKEDA** \\ Department of Neurosugery and *Pathology, \\ School of Medicine, Gunma University, Maebashi, Japan \\ ** Department of Neurosurgery, \\ Saitama Cancer Center, \\ Saitama, Japan
}

\begin{abstract}
Summary
Ultrastructural features of the secretory granules of human pituitary adenomas obtained at operation from 18 patients were studied in correlation with the clinical features and abilities of the tumor tissue to synthesize and release growth hormone $(\mathrm{HGH})$ and prolactin. These abilities were measured quantitatively, isolating the hormones with polyacrylamide gel disc electrophoresis after in vitro labelling of the hormones with ${ }^{14} \mathrm{C}$ leucine. The pituitary adenomas without recognizable functional significance ( 8 cases), which clinically manifested hypopituitarism, showed low hormone synthesis. In the cytoplasm, small secretory granules $(100-200 \mathrm{~nm}$ in diameter) covered with a limiting membrane and having a clear halo and dense core were sparsely distributed. In prolactin producing adenomas, which clinically manifested hyperprolactinemia with galactorrheaamenorrhea syndrome ( 3 cases), higher prolactin synthesis was found. In the tumor cells, round and pleomorphic secretory granules were observed. The latter, measuring up to 450 $\mathrm{nm}$ in diameter, were considered to be prolactin granules. Round secretory granules measuring $150-350 \mathrm{~nm}$ in diameter were commonly observed in the adenomas showing high HGH synthesis function and/or elevated plasma HGH concentration. This type of granules were common in $\mathrm{HGH}$ producing adenomas clinically manifesting acromegaly (5 cases), and, therefore, were considered as HGH granules. Though less irregularly-shaped than in prolactin producing adenomas, pleomorphic secretory granules were also found in the $\mathbf{H G H}$ producing adenomas together with the round granules. The high prolactin synthesis and release functions of the HGH producing adenomas would be correlated to the presence of this type of granules. There were two tumors in which the ultrastructural appearance could not be correlated with clinical features or measured abilities of the hormone synthesis and release.
\end{abstract}

Key words: Electron microscopy, human pituitary adenoma, secretory granules, hormone synthesis and release

\section{Introduction}

Recent researches of pituitary adenomas which utilized electron microscopy or tissue

This work was presented at the 35th Annual Meeting of Japan Neurosrugical Society, Maebashi, October 22, 1976. culture strongly suggested that even a pituitary adenoma which was clinically considered to be non-functioning (pituitary adenoma without recognizable functional significance ${ }^{2 \jmath}$ ) produced a limited amount of hormones. The meticulous histological survey reported by McCormick and Halmi $^{13)}$ showed absence of chromophobe adenomas in a large series of the pituitary tumors. Thus, the classical mode of classification 
of the pituitary adenomas is now obsolete. Many publications have contributed to the advances in electron microscopic research of human pituitary tumors. They have disclosed the ultrastructure of pituitary adenomas in correlation with clinico-endocrinological features, ${ }^{6,15,18)}$ histological findings ${ }^{12,18}$ ) or ultrastructural appearances of the anterior pituitaries of humans and experimental animals. ${ }^{10,15,19)}$ The abilities of the tumor to secrete hormones in tissue culture ${ }^{7)}$ or hormone assay of the tumor tissue ${ }^{14)}$ have also been studied.

The purpose of this paper is to present the ultrastructural features of human pituitary adenomas and to discuss the functional signifcance of the secretory granules in correlation with the clinico-endocrinological features, as well as the abilities of the same tumor tissue to synthesize and release growth hormone $(\mathrm{HGH})$ and prolactin in vitro.

\section{Materials and Methods}

Fresh tissue samples of human pituitary adenoma were obtained from 18 patients of both sexes, when the tumor was removed via a frontobasal or transsphenoidal approach.

According to the preoperative signs, symptoms and endocrinological findings, the patients were classified into the following 3 groups (Table 1): In Group 1, 9 patients manifested signs and symptoms of pituitary hypofunction and ocular symptoms such as atrophy of the optic nerves and defects of the visual fields. Each pituitary hormone concentration in plasma, measured preoperatively by means of radioimmunoassay, was lower in the patients than in normal humans, and an appropriate stimulus made by insulin, TRH or LH-RH provoked only a decreased response. The patients harbored pituitary adenoma without recognizable functional significance. In Group 2, preoperative prolactin concentration in plasma estimated in 4 patients was exceedingly elevated before and after intravenous administration of TRH. All 4 of them manifested a galactorrhea-amenorrhea syndrome. The tumor was considered to be a functioning adenoma, producing excessive amounts of prolactin. In Group 3, all 5 patients showed acromegaly. HGH concentration in plasma was abnormally elevated even at rest in all of the 5 cases, and in one of them, plasma prolactin concentration was also exceedingly elevated. The tumor was considered to be an HGH producing adenoma.

The operative specimens of the adenoma tissue from 18 patients were immediately fixed for 1 hour at $4{ }^{\circ} \mathrm{C}$ in $2.5 \%$ glutaraldehyde buffered with $0.2 \mathrm{M}$ sodium phosphate buffer at pH 7.3. After multiple washings over 24 hours in the same buffer, the tissue blocks were postfixed for 1.5 hour in $2 \%$ osmium tetroxide in the above buffer. Subsequently the tissue was dehydrated in chilled ethanol, immersed in propyrene oxide, and embedded in Epon. Ultrathin sections were stained in alcoholic uranyl acetate

Table 1 Clinico-endocrinological features of the patients.

\begin{tabular}{|c|c|c|c|c|c|c|c|}
\hline \multirow[b]{2}{*}{ Group } & \multirow[b]{2}{*}{$\begin{array}{c}\text { No. of } \\
\text { cases }\end{array}$} & \multirow[b]{2}{*}{$\begin{array}{c}\text { Age in } \\
\text { years }\end{array}$} & \multirow[b]{2}{*}{ Endocrinological state } & \multicolumn{2}{|c|}{ Plasma HGH (ng/ml) } & \multicolumn{2}{|c|}{ Plasma PRL (ng/ml) } \\
\hline & & & & $\begin{array}{l}\text { Resting } \\
\text { level }\end{array}$ & $\begin{array}{l}\text { Peak value } \\
\text { induced by } \\
\text { i.v. insulin }\end{array}$ & $\begin{array}{c}\text { Resting } \\
\text { level }\end{array}$ & $\begin{array}{l}\text { Peak value } \\
\text { induced by } \\
\text { i.v. TRH }\end{array}$ \\
\hline 1 & 9 & $30-58$ & $\begin{array}{l}\text { Low plasma pituitary } \\
\text { hormone concentration } \\
\text { with hypopituitarism }\end{array}$ & $2.3-3.7$ & $2.1-15.0$ & $1.3-32.4$ & $11.9-68.0$ \\
\hline 2 & 4 & $29-38$ & $\begin{array}{l}\text { Elevated plasma PRL } \\
\text { concentration with } \\
\text { galactorrhea-amenorrhea } \\
\text { syndrome }\end{array}$ & $2.4-12.0$ & $5.1-12.5$ & $960-1300$ & $1090-7250$ \\
\hline 3 & 5 & $37-45$ & $\begin{array}{l}\text { Elevated plasma HGH } \\
\text { concentration with } \\
\text { acromegaly }\end{array}$ & $18-58$ & $68-388$ & $\begin{array}{c}0 \text {-scale } \\
\text { out }\end{array}$ & $\begin{array}{c}0 \text {-scale } \\
\text { out }\end{array}$ \\
\hline
\end{tabular}

PRL: prolactin. 
and lead nitrate prior to electron microscopy and photography.

HGH synthesis and release functions as well as prolactin synthesis and release functions of the adenoma tissues were separately measured in 14 cases, isolating these hormones with polyacrylamide gel disc electrophoresis after in vitro labelling of the hormones with ${ }^{14} \mathrm{C}$-leucine. An appropriate amount of the sliced adenoma tissue was incubated in $0.2 \mathrm{ml}$ Krebs-Ringer bicarbonate buffer solution, $\mathrm{pH} 7.3$, which contained $360 \mu \mathrm{g}$ glucose and $0.2 \mu \mathrm{Ci}{ }^{14} \mathrm{C}$-leucine. After incubation for 3 hours, the adenoma tissue and incubation medium were separately treated as described elsewhere ${ }^{14}$ ) for subsequent polyacrylamide gel disc electrophoresis. The bands of $\mathrm{HGH}$ and prolactin in the gel column were dissected, made transparent to scintillation, and counted with a Beckman liquid scintillation spectrometer, Model LS 200B, for the radioactivity (cpm) of ${ }^{14} \mathrm{C}$-leucine which was incorporated into these hormones during the incubation. The abilities of the adenoma tissue to synthesize and release hormones were determined using the following parameters:

Hormone synthesis function: $(t+m) / \mathrm{mg}$ wet tissue,
Hormone release function:

$$
100 \times m /(t+m)
$$

where $t(\mathrm{cpm})$ is the radioactivity of newly synthesized hormone during incubation and retained in the tissue, and $m(\mathrm{cpm})$ is that of the hormone newly synthesized and released into the medium. The term $100 \times m /(t+m)$ is the percent release of the newly synthesized hormone. The hormone synthesis and release functions were thus estimated separately.

\section{Results}

Group I (adenoma without recognizable functional significance)

Quantitative measurement of the abilities of the adenoma tissues to synthesize and release $\mathrm{HGH}$ and prolactin was performed in 7 cases of this group (Table 2). The results revealed that all of the 7 adenoma tissues synthesized and released $\mathrm{HGH}$ and prolactin. The hormone synthesis function was low in most cases when compared with the other 2 groups. The hormone release function was variable from case to case, though the amount of released hormones was extremely small.

Electron microscopy revealed that the ade-

Table 2 Hormone synthesis and release functions estimated with the in vitro experiment.

\begin{tabular}{|c|c|c|c|c|c|c|}
\hline Group & \multicolumn{2}{|c|}{ Case } & $\begin{array}{c}\text { HGH synthesis } \\
\text { function } \\
\text { (cpm/mg wet tissue) }\end{array}$ & $\begin{array}{l}\text { HGH release } \\
\text { function } \\
(\%)\end{array}$ & $\begin{array}{l}\text { Prolactin synthesis } \\
\text { function } \\
\text { (cpm/mg wet tissue) }\end{array}$ & $\begin{array}{l}\text { Prolactin release } \\
\text { function } \\
(\%)\end{array}$ \\
\hline \multirow{9}{*}{1} & TA & 우 & 88.2 & 39.7 & 107.0 & 50.4 \\
\hline & YN & $\hat{\sigma}$ & 102.0 & 48.4 & 168.5 & 31.2 \\
\hline & KT & 우 & 126.6 & 10.7 & 174.1 & 13.9 \\
\hline & SK & $\hat{0}$ & 82.8 & 23.7 & 128.6 & 18.3 \\
\hline & GK & 우 & 43.8 & 48.6 & 37.2 & 35.8 \\
\hline & SI & 우 & \multirow{2}{*}{\multicolumn{2}{|c|}{$\begin{array}{l}\text { not measured } \\
\text { not measured }\end{array}$}} & \multirow{2}{*}{\multicolumn{2}{|c|}{$\begin{array}{l}\text { not measured } \\
\text { not measured }\end{array}$}} \\
\hline & AM & 우 & & & & \\
\hline & TT & $\hat{\delta}$ & 134.0 & 42.1 & 112.5 & 22.9 \\
\hline & $\mathrm{EF}$ & 우 & 70.4 & 24.7 & 138.0 & 21.8 \\
\hline \multirow{4}{*}{2} & MK & 우 & 138.5 & 60.4 & 137.0 & 51.4 \\
\hline & KM & 우 & 173.0 & 57.2 & 367.6 & 78.1 \\
\hline & AW & 우 & 885.3 & 25.0 & 265.8 & 37.1 \\
\hline & MA & 우 & 105.0 & 33.3 & 145.7 & 24.7 \\
\hline \multirow{5}{*}{3} & CI & 우 & 2167.0 & 89.5 & 1689.0 & 88.6 \\
\hline & $\mathrm{KO}$ & 우 & 1307.0 & 26.3 & 764.0 & 26.9 \\
\hline & FI & 우 & 651.8 & 32.2 & 792.8 & 23.1 \\
\hline & KT & 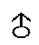 & \multirow{2}{*}{\multicolumn{2}{|c|}{$\begin{array}{l}\text { not measured } \\
\text { not measured }\end{array}$}} & \multirow{2}{*}{\multicolumn{2}{|c|}{$\begin{array}{l}\text { not measured } \\
\text { not measured }\end{array}$}} \\
\hline & IK & 우 & & & & \\
\hline
\end{tabular}




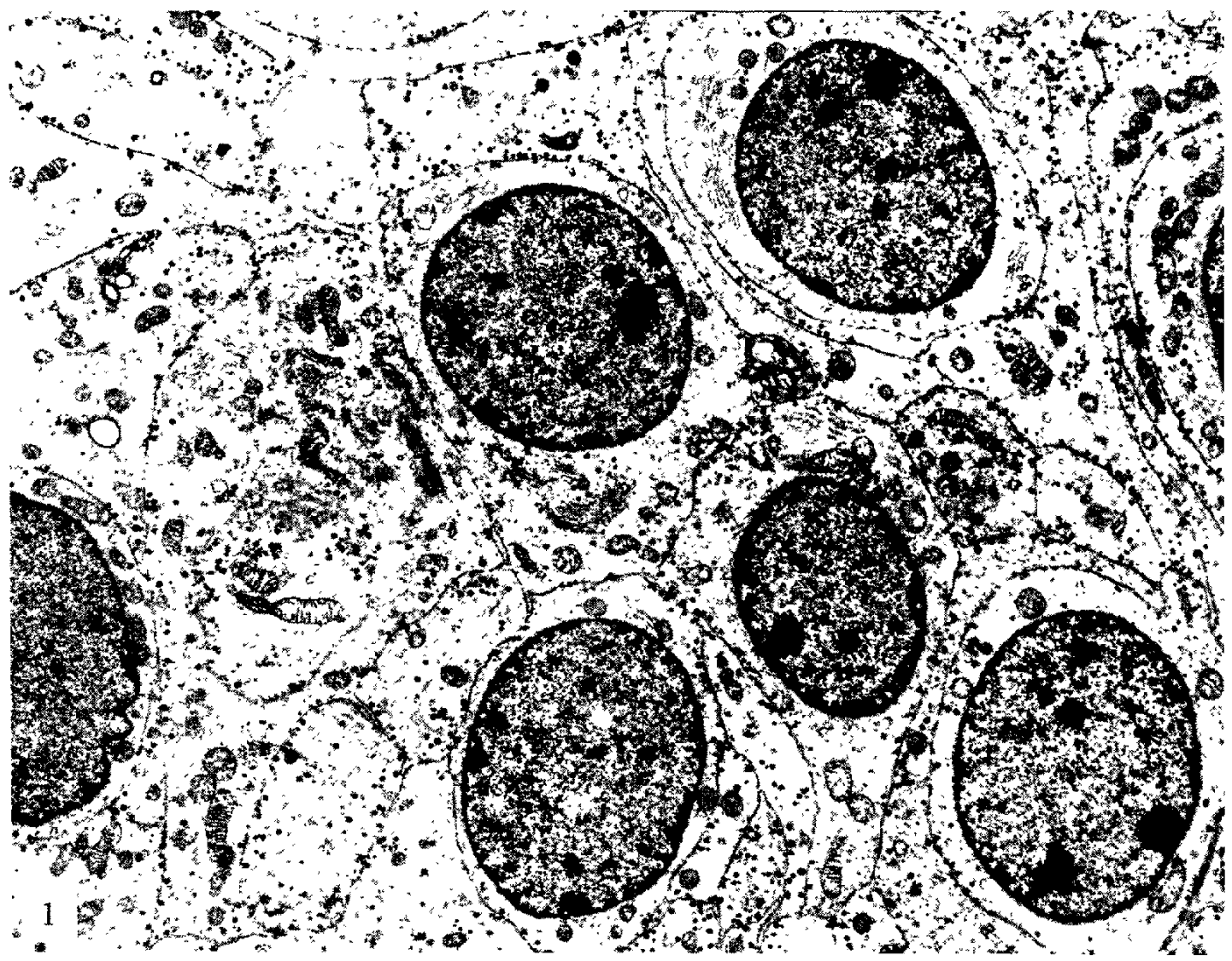

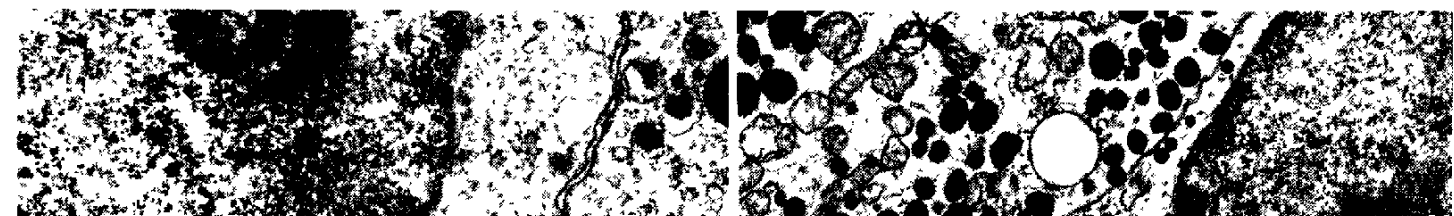
13.

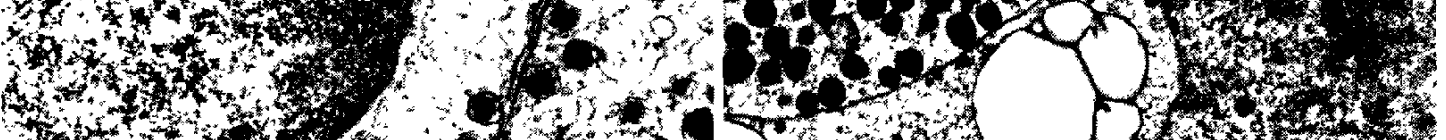

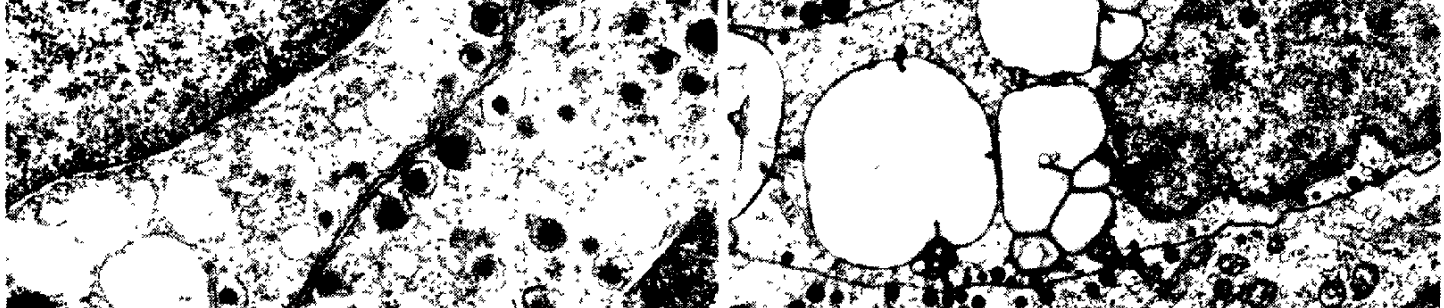

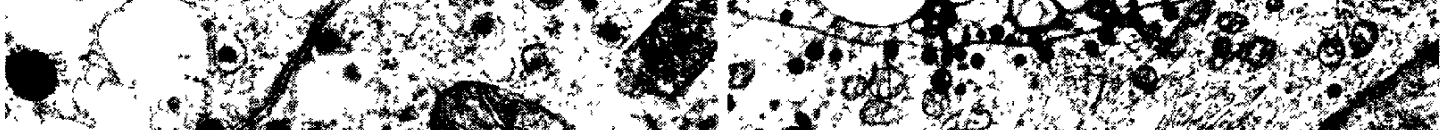

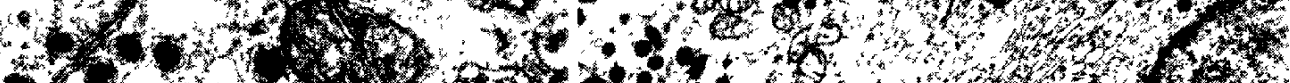
(n) 
noma tissues had two different types of ultrastructure. In 8 cases, the adenoma tissues were composed of polygonal cells with an ovoid or round nucleus in the center. The nucleoli were indistinct. The cytoplasm contained round, moderately dense secretory granules measuring $100-200 \mathrm{~nm}$ in diameter. They were usually sparse and lined up along the cell membrane (Fig. 1). In general, each granule was covered with a limiting membrane, leaving a clear halo between the membrane and the dense core (Fig. 2). The number of mitochondria varied from one tumor to another, and there was no abnormality in the ultrastructural organization of the mitochondria. The Golgi apparatus was frequently encountered, and some of the secretory granules were found within it. The endoplasmic reticulum were at times abundant in the cytoplasm. The ultrastructural features of the adenoma tissues closely resembled those of undifferentiated cell adenoma (Horvath and $\mathrm{Kovac}^{6)}$ ), type 2 chromophobe adenomas (Kuromatsu ${ }^{8}$ ) and the ultrastructural appearance of chromophobe adenomas described by Schelin. ${ }^{18)}$

In the remaining case (Case EF), the adenoma tissue was composed of polygonal cells which contained abundant cell organelles. There were adenoma cells of two types intermingled with each other (Fig. 3). The small round secretory granules measuring $100-300 \mathrm{~nm}$ in diameter were sparsely distributed in the cytoplasm of some

Fig. 1. Adenoma without recognizable functional significance (Group 1, Case AM). In the cytoplasm of the polygonal tumor cells are observed sparsely distributed small round secretory granules. Most of them are lined up along the cytoplasmic membrane. $\times 6,400$.

Fig. 2. Small round secretory granules observed in the adenoma without recognizable functional significance (Group 1, Case TA). Note the limiting membrane, a clear halo and dense core. The diameter ranged from $100-200 \mathrm{~nm}$. $\times 20,000$.

Fig. 3. Adenoma from Case EF (Group 1) in which no correlation was observed. Two types of the adenoma cells are present intermingling with each other. In some of them, round small secretory granules measuring $100-300 \mathrm{~nm}$ in diameter are sparsely contained, while numerous round and pleomorphic secretory granules measuring $350-600 \mathrm{~nm}$ in diameter are densely contained in the other. $\times 6,500$. cells, and in the others, numerous round and pleomorphic secretory granules measuring 350$600 \mathrm{~nm}$ in diameter were densely packed. The hormone synthesis function of this particular adenoma tissue was as low as in the 8 cases described above (Table 2).

Group 2 (prolactin producing adenomas with galactorrhea)

In 3 cases in this group, $\mathrm{HGH}$ synthesis function was higher than those in the cases of Group 1 (Table 2), and in one case it was extremely high. The prolactin synthesis and release functions were also highed in 2 cases than in the cases of Group 1. These differences may be responsible, at least partly, for the high plasma prolactin concentration in this group (Table 1).

Electron microscopy indicated that the adenoma tissues from 3 cases with galactorrheaamenorrhea syndrome were composed of polyhedral tumor cells, some of which possessed microvilli. The nuclei were irregularlyshaped. In the cytoplasm, pleomorphic secretory granules measuring up to $450 \mathrm{~nm}$ in diameter and round granules measuring $150-300 \mathrm{~nm}$ in diameter were variably mixed (Fig. 4). Both granules were electron dense. They were moderately abundant in 1 case, while sparse in the others. The pleomorphic granules were usually rod- or comma-shaped (Fig. 5), and exocytosis of granules (usually of round ones) was frequently observed (Fig. 6). There were abundant endoplasmic reticulum in the cytoplasm. Mitochondria were often numerous, and their cristae were frequently deformed. The Golgi apparatus was frequently encountered, containing some small granules within it. The ultrastructure of the adenomas closely resembled the prolactin cell adenomas described by Horvath and Kovac, ${ }^{6)}$ some of chromophobe adenomas by Kuromatsu, ${ }^{8)}$ and those observed by Racadot et al. ${ }^{15)}$

In the remaining case (Case MA), the adenoma tissue was composed of tumor cells containing sparsely distributed small secretory granules, similar to those observed in the 8 cases in Group 1. The abilities to synthesize and release $\mathrm{HGH}$ and prolactin were found to be low, though galactorrhea-amenorrhea syndrome was clinically manifested. 


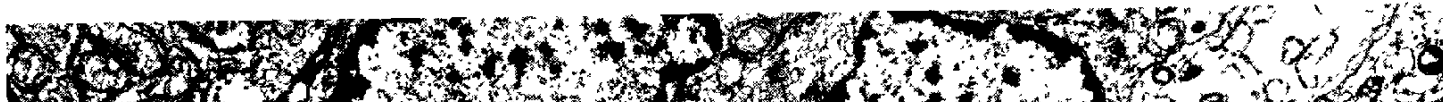

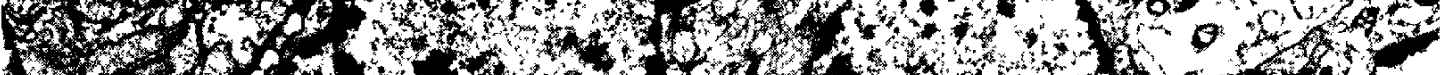

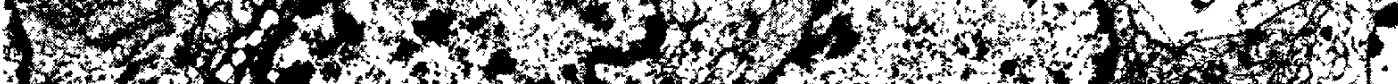

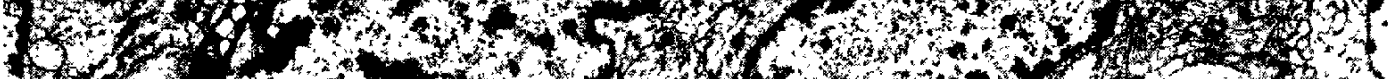

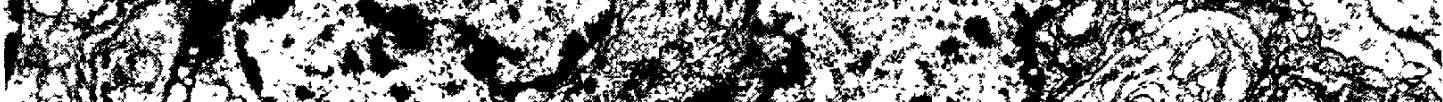

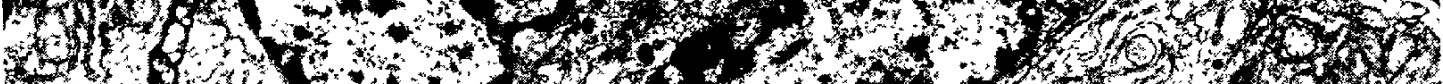

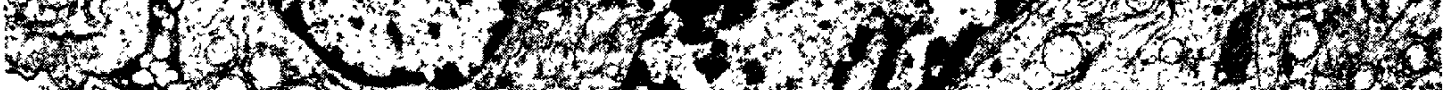

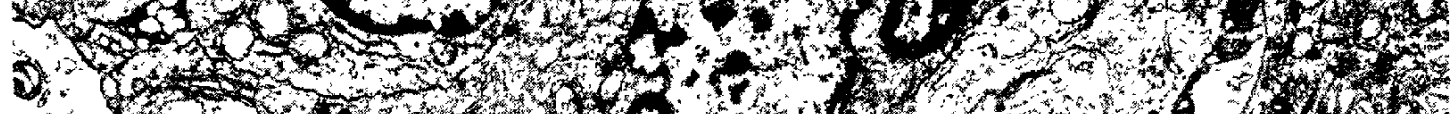

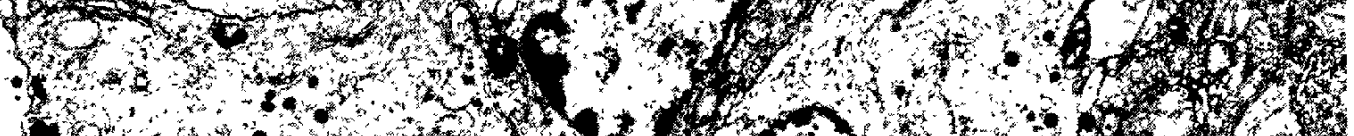

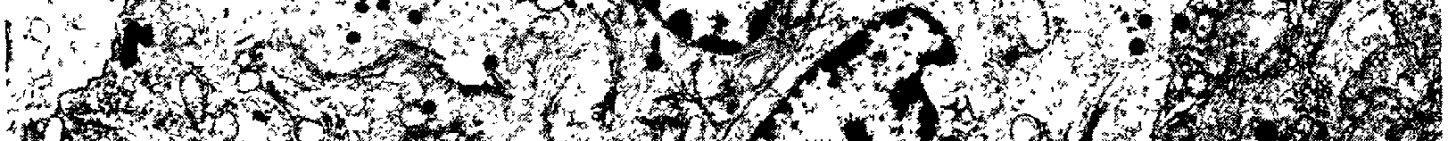

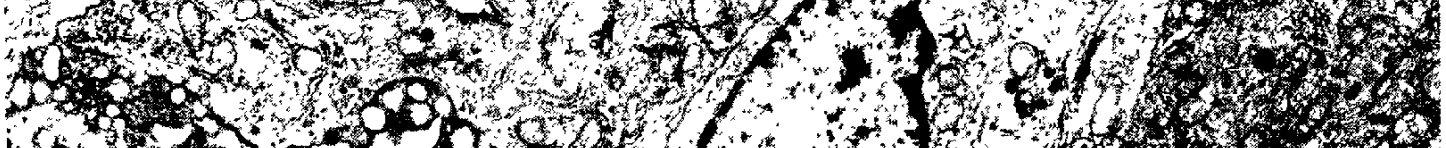

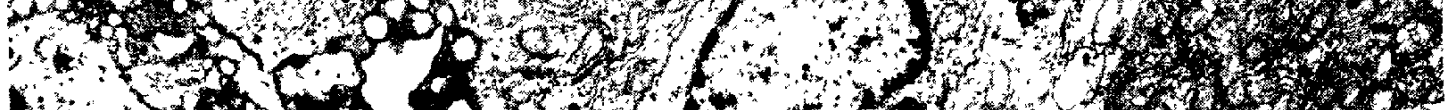

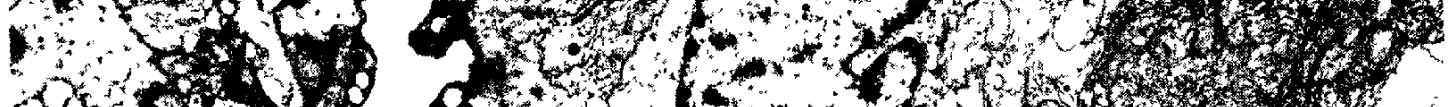

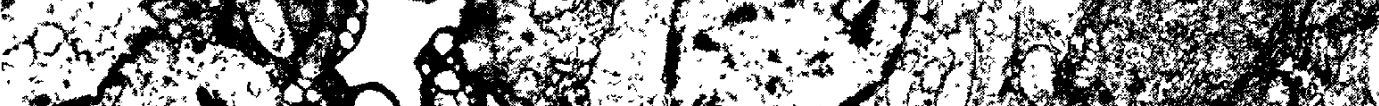

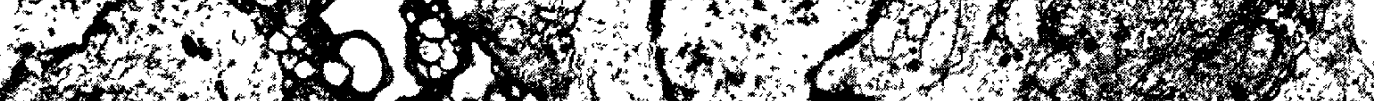

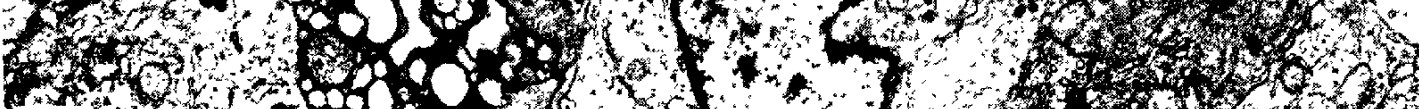
F.

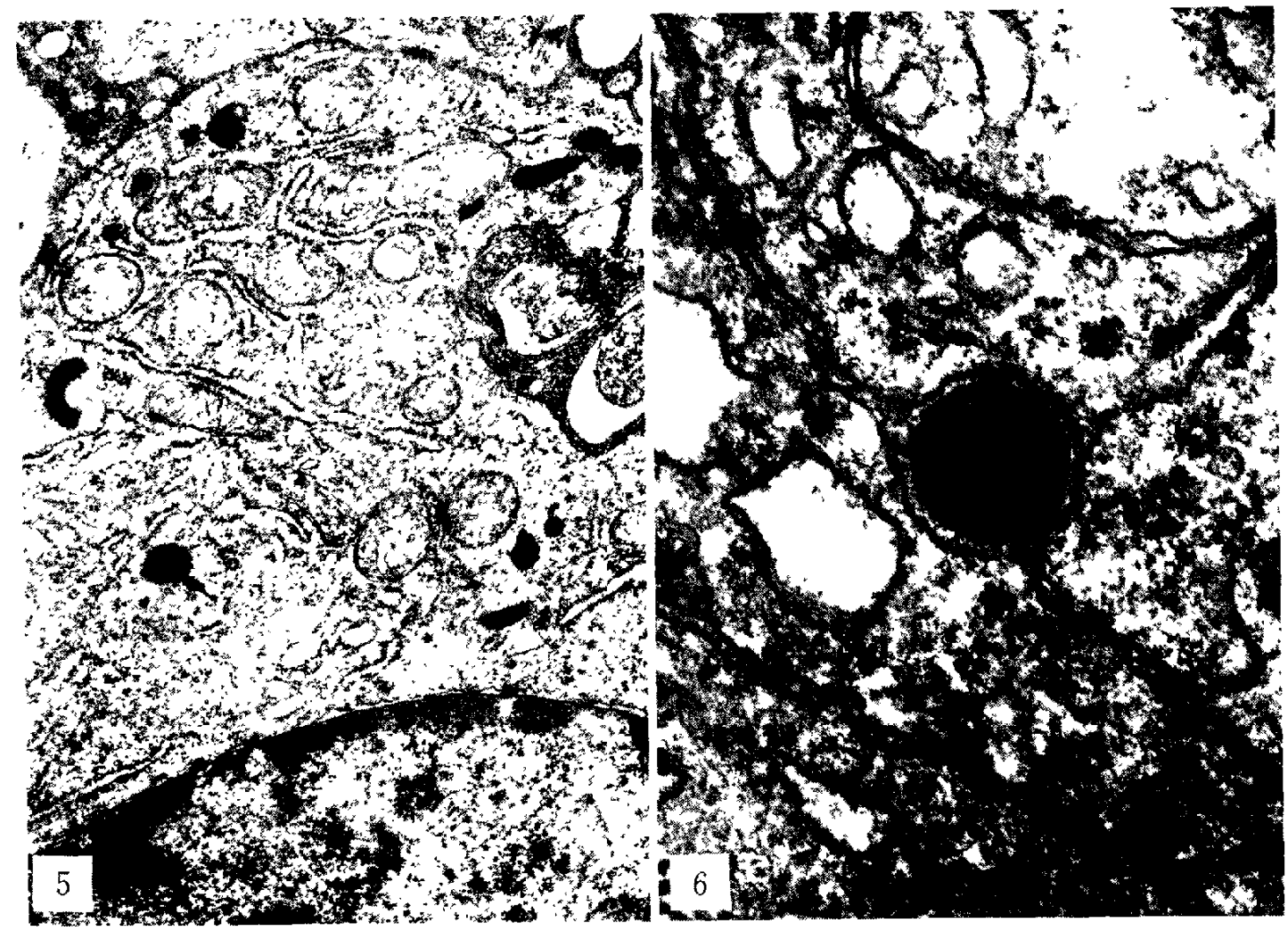


Group 3 (HGH producing adenomas with acromegaly)

The abilities to synthesize and release $\mathrm{HGH}$ and prolactin were measured in 3 cases out of 5 . HGH synthesis and prolactin synthesis were very high in all 3 cases (Table 2). HGH release was very high in 1 case, and prolactin release was also high in this case.

Electron microscopic observation in a case (Case CI, Fig. 7), in which abnormally elevated plasma concentration of $\mathrm{HGH}$ and prolactin was clinically evaluated, revealed irregularlyshaped tumor cells with abundant microvilli. The nuclei were also irregularly-shaped. Secretory granules were relatively abundant, and most of them were round, measuring $200-400 \mathrm{~nm}$ in diameter; a few were pleomorphic (mostly irregular-ovoid), measuring 200-600 $\mathrm{nm}$ in diameter. Both type of granules were intermingled within the same tumor cells. Numerous cisternae of the rough endoplasmic reticulum and mitochondria were present, and the cristae of mitochondria were abnormally deformed. The Golgi apparatus was frequently encountered.

The adenoma tissue from 2 other cases, which clinically showed abnormally elevated plasma $\mathrm{HGH}$ and normal plasma prolactin concentrations, were composed of polygonal tumor cells without microvilli. The nuclei were round or ovoid. There were no abnormalities in the Golgi apparatus and mitochondria. Secretory granules were sparsely distributed in the cytoplasm. Most cells contained round granules measuring 100 $300 \mathrm{~nm}$ in diameter, while some other cells contained pleomorphic secretory granules measuring up to $800 \mathrm{~nm}$ in diameter. Both types of cells were intermingled with each other (Fig. 8). In the cytoplasm of the former cells with round

Fig. 4. Prolactin producing adenoma (Group 2, Case MK). In the cytoplasm of polyhedral tumor cells with irregularly-shaped nuclei, there are sparsely distributed pleomorphic secretory granules. Endoplasmic reticulum is abundant. Some of the secretory granules are present within the Golgi apparatus. $\times 5,200$.

Fig. 5. Prolactin producing adenoma (Group 2, Case MK). The pleomorphic secretory granules are usually rod-or comma-shaped. The diameter measured up to $450 \mathrm{~nm} . \times 20,000$.

Fig. 6. Prolactin producing adenoma (Group 2, Case MK). Exocytosis of the secretory granules are frequently observed. $\times 6,500$. granules, there were frequently observed intracytoplasmic accummulation of fine filaments, within which some of the granules and mitochondria were encountered (Fig. 9). These two adenomas closely resembled mixed adenomas composed of $\mathrm{GH}$ and prolactin cells (Horvath and $\mathrm{Kovac}^{6)}$ and Corenblum ${ }^{1)}$ ).

In the remaining 2 cases, in vitro estimation of hormone synthesis and release functions was not performed. They clinically showed an abnormally elevated plasma $\mathrm{HGH}$ and low prolactin concentrations. The adenoma tissues were composed of polygonal tumor cells with round nuclei. The secretory granules were abundant in the cytoplasm (Fig. 10). There were round granules measuring $150-300 \mathrm{~nm}$ in diameter and pleomorphic granules measuring 350 $600 \mathrm{~nm}$ in diameter. The latter were somewhat less irregularly-shaped than in the other adenomas. The round granules were observed predominantly in some tumor cells, while the pleomorphic granules were numerous in the other cells. Intracytoplasmic accummulation of fine filaments was not observed. The ultrastructure of the adenoma closely resembled densely granulated GH cell adenoma (Horvath and Kovac $^{6)}$ ) and those described by Schelin, ${ }^{18)}$ and Racadot et al., ${ }^{15)}$ though they hardly mentioned the pleomorphic secretory granules.

\section{Discussion}

Since 1974, the abilities of human pituitary adenoma tissues to synthesize and release hormones have been studied by our colleagues. ${ }^{6,14}$ ) Employing appropriate parameters, two distinct functions of the tumor tissues, hormone synthesis and release, were quantitatively measured. The results showed that all of the adenoma tissues obtained at operation from those cases with "chromophobe" and "eosinophilic" adenomas synthesized and released $\mathrm{HGH}$ and prolactin in variable amounts (Sasaki et al. ${ }^{16}$ ) and Fujii et $\left.a^{4}{ }^{4}\right)$. Though the present materials were not large enough, and did not contain pituitary adenomas manifesting Cushing's syndrome, it was considered worthwhile to discuss the electron microscopic findings of a pituitary adenoma in correlation with their abilities to synthesize and release hormones.

The results of the experiment indicated that even pituitary adenomas without recognizable 


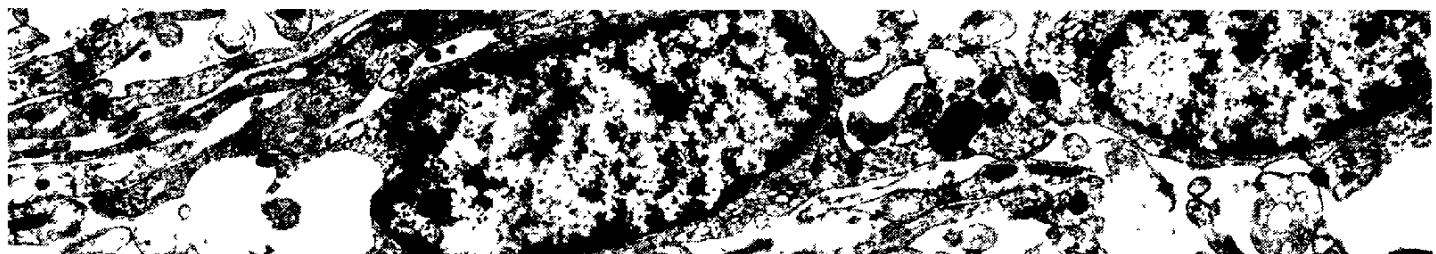

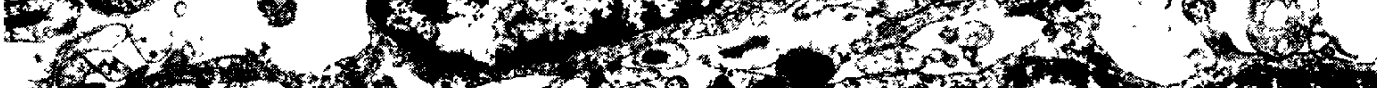

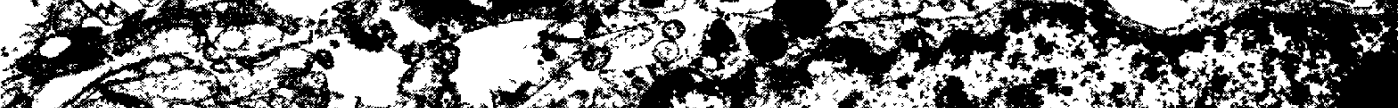

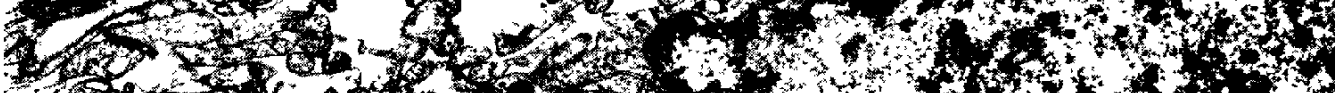

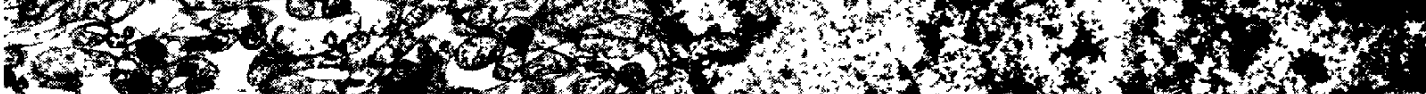

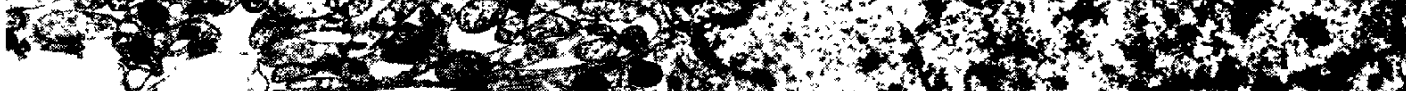
(1)

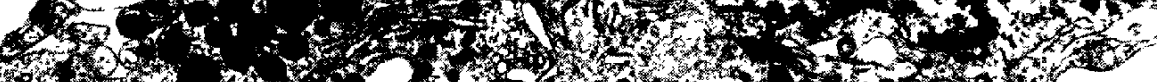

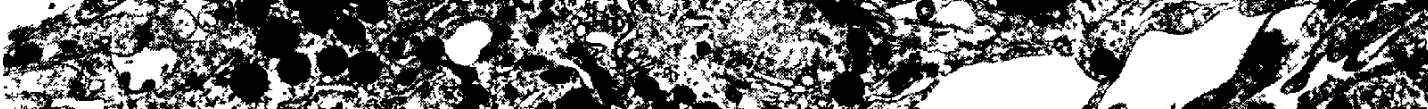

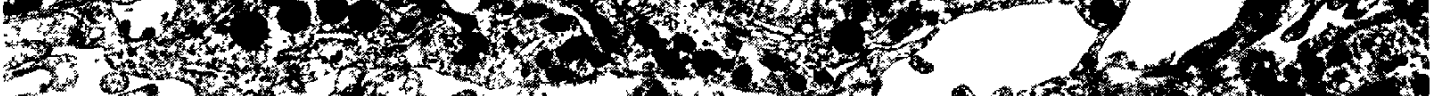

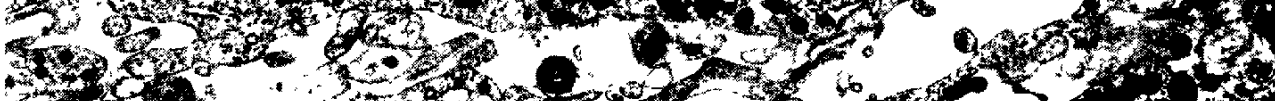

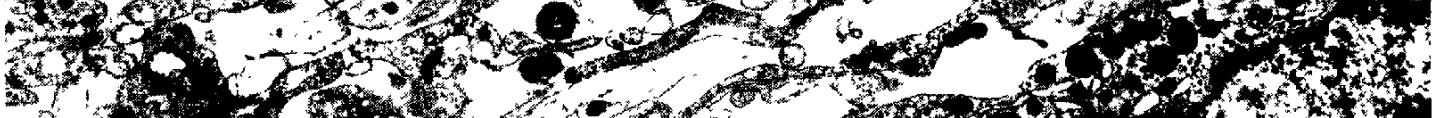

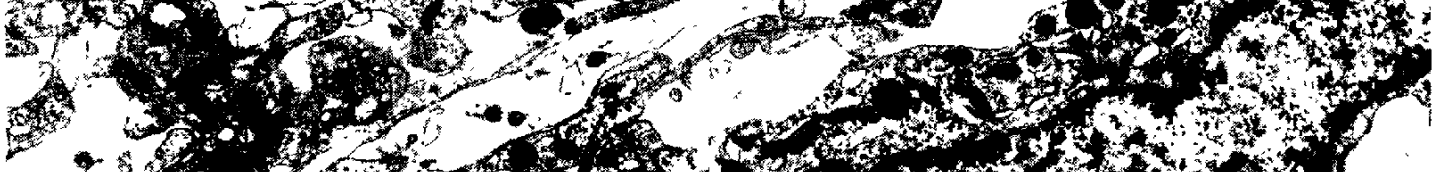

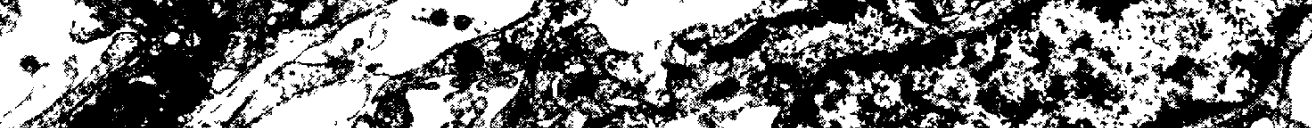

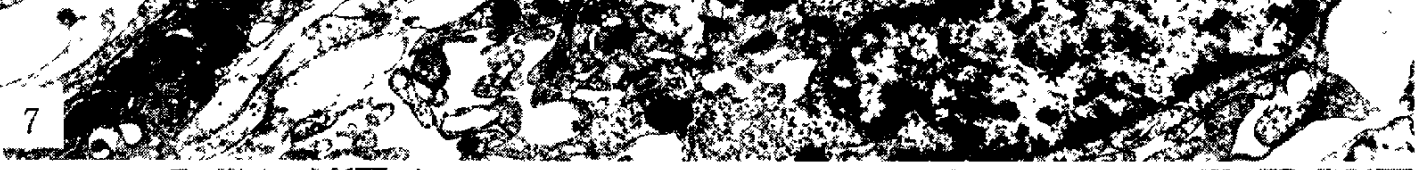

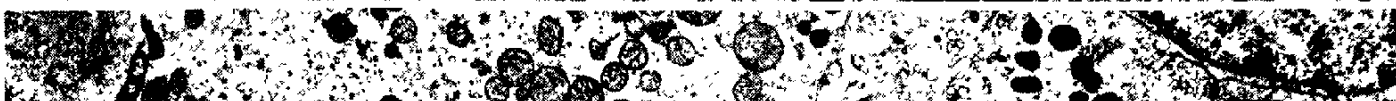

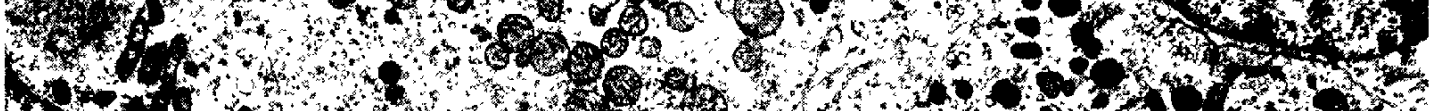

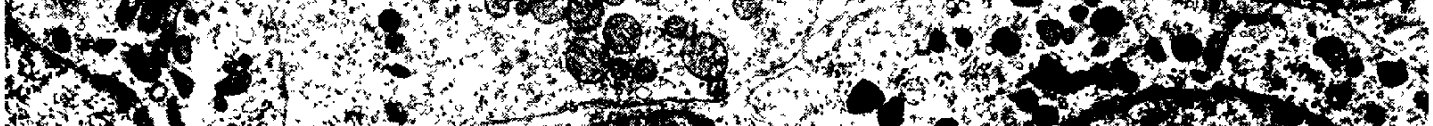
4.

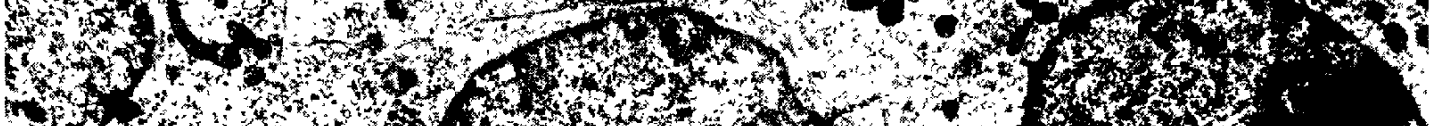

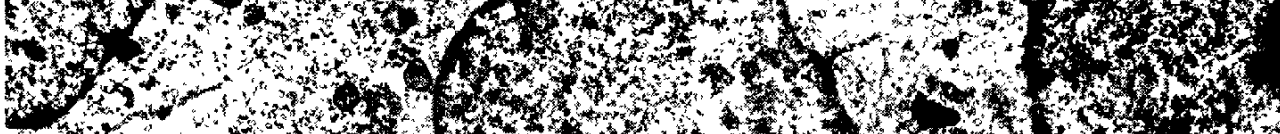

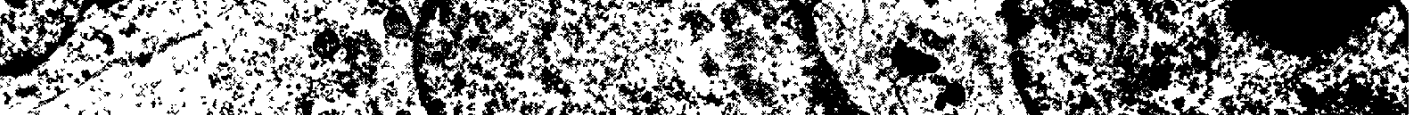

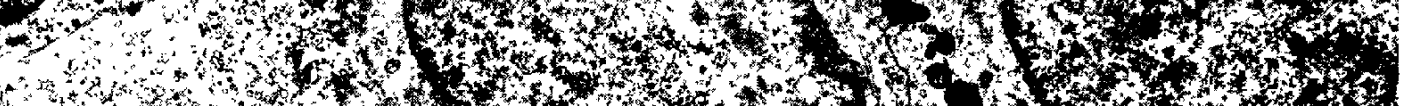

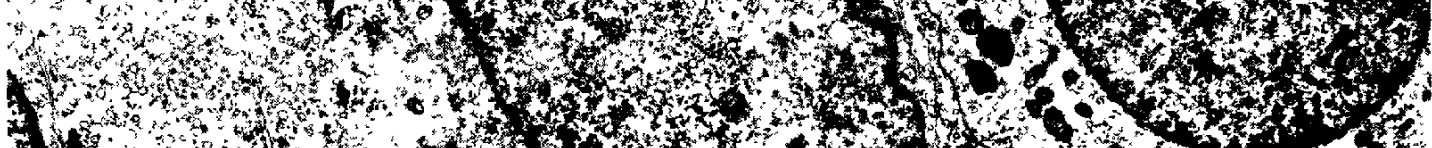

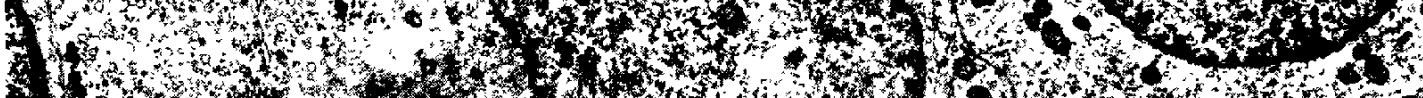

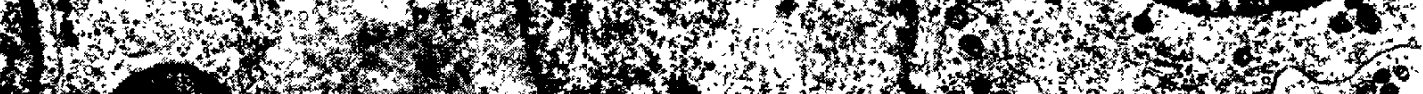

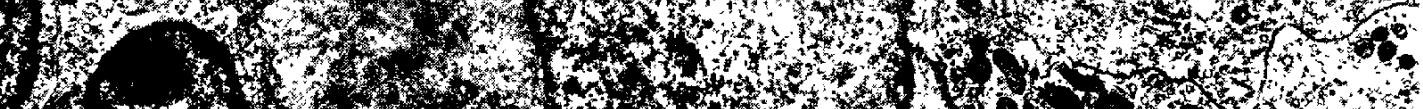

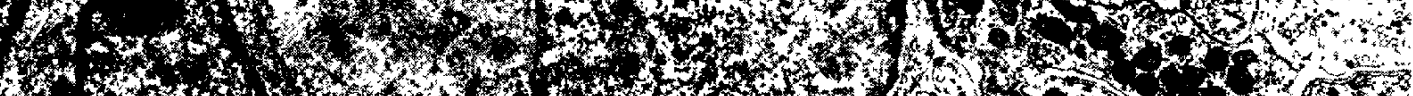

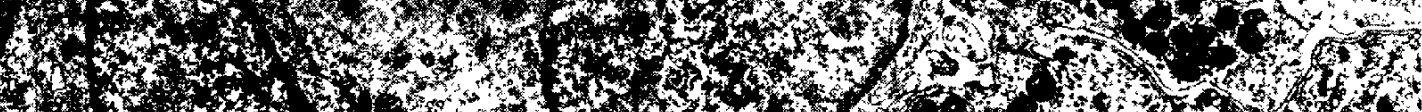

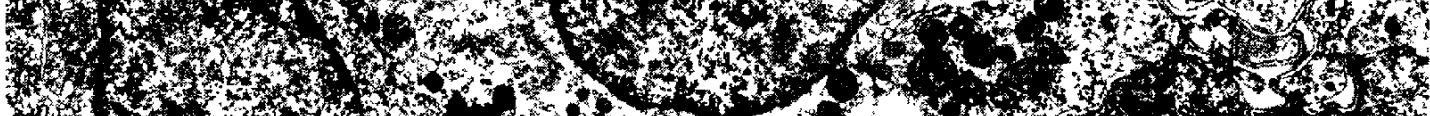

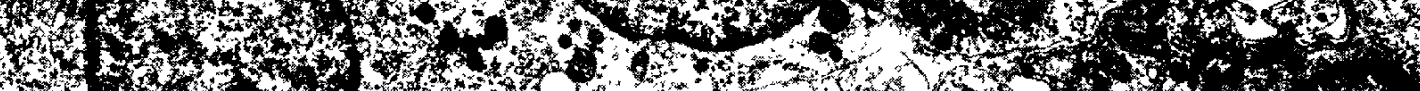
13.

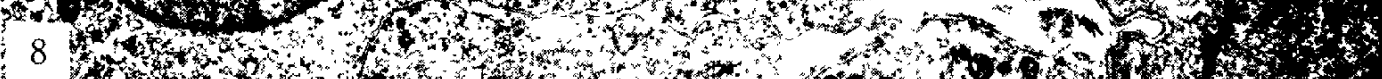

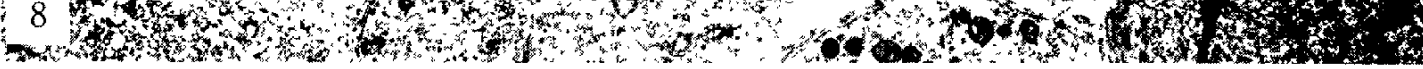




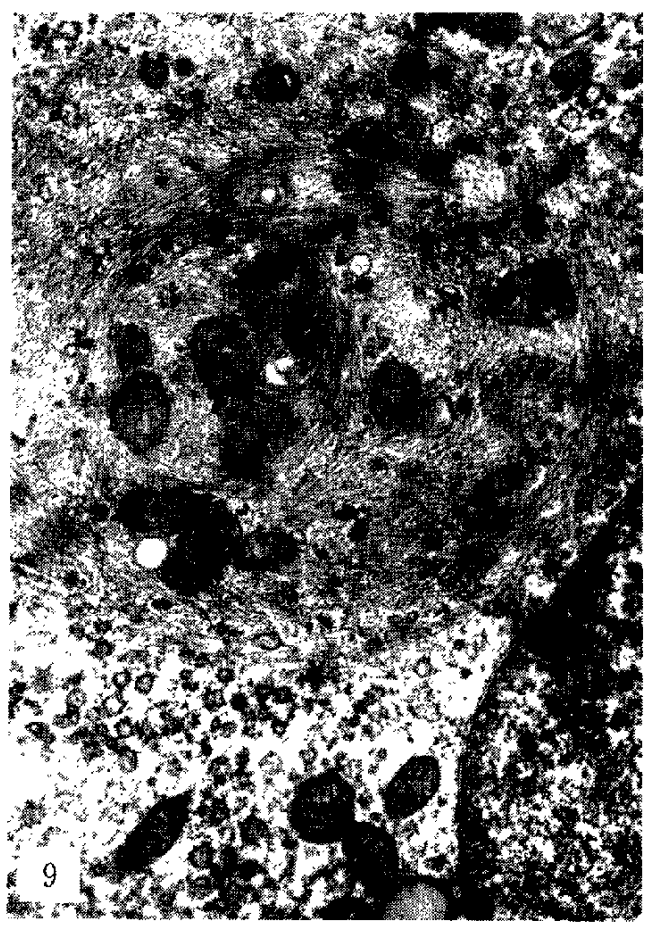

Fig. 7. HGH producing adenoma (Group 3, Case CI). The adenoma cells have abundant microvilli and irregularly-shaped nuclei. Secretory granules are relatively abundant. Most of them are round measuring $200400 \mathrm{~nm}$ in diameter, and a few are pleomorphic or irregularly-shaped measuring $200-600 \mathrm{~nm}$ in diameter. Both granules are intermingled with each other in the same tumor cells. The cytoplasmic organelles are abundant. $\times 7,600$.

Fig. 8. HGH producing adenoma (Group 3, Case FI). Some of the adenoma cells contained round secretory granules measuring $100-300 \mathrm{~nm}$ in diameter, while others contained pleomorphic granules measuring up to $800 \mathrm{~nm}$ in diameter. In the cytoplasm of the former cells, intracytoplasmic accummulation of fine filaments are frequently observed. $\times 5,100$.

Fig. 9. High magnification of the intracytoplasmic accummulation of fine filaments, in which some of the secretory granules and mitochondria are usually observed (Group 3, Case FI). $\times 20,000$.

Fig. 10. HGH producing adenoma (Group 3, Case IK). The cytoplasm of polygonal cells contained round as well as pleomorphic secretory granules. The round granules measuring $150-300 \mathrm{~nm}$ in diameter are predominantly encountered in some cells, while the pleomorphic granules measuring $350-600 \mathrm{~nm}$ in diameter are numerous in others. $\times 4,000$.

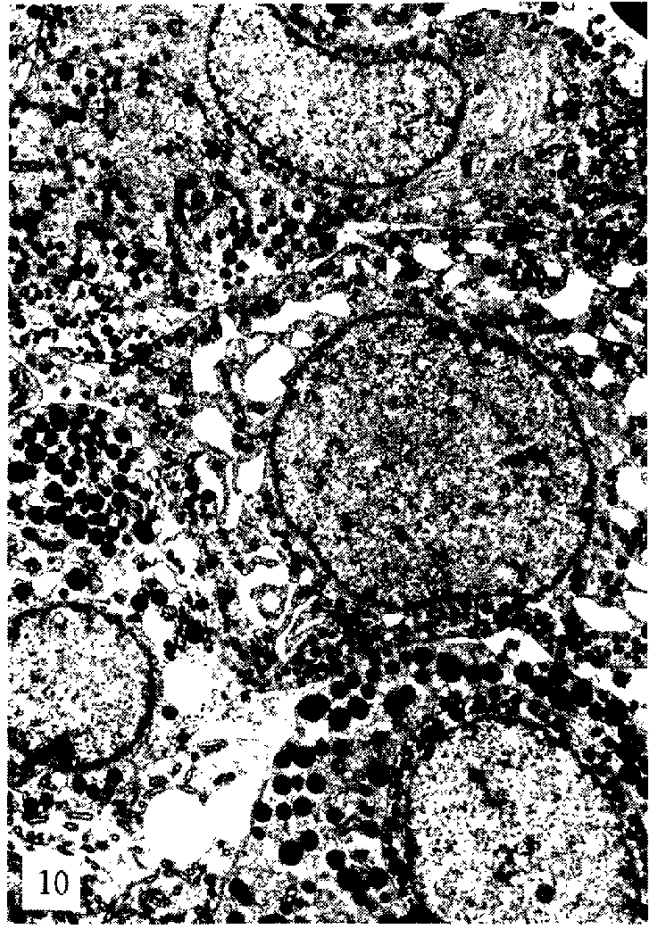

functional significance synthesized and released $\mathrm{HGH}$ and prolactin. However, the amount was so small that their secretion would not have any detectable biological or clinical effect. In the cytoplasm, there were only small secretory granules with a limiting membrane, a clear halo and dense core, which might be considered as morphological manifestation of intracellular processes to synthesize and release a small amount of HGH and prolactin. Similar secretory granules were observed in human anterior pituitaries, ${ }^{20)}$ and also in the series of "chromophobe" adenomas studied by Horvath and Kovac, ${ }^{6)}$ Kuromatsu $^{8)}$ and Racadot et al. ${ }^{15)}$ Since the abilities of the adenomas to synthesize and release other hormones were not yet determined, it remained unclear whether the secretory granules were associated with $\mathrm{ACTH}$, TSH or with gonadotropins.

In the cytoplasm of the tumor cells obtained from 3 cases in Group 2 (prolactin producing adenomas), there were secretory granules of two distinct morphological characteristics intermingling with each other. The pleomorphic (rod- or comma-shaped) granules, were observed specifically in the tumor cells from the cases which clinically showed exceedingly elevated plasma prolactin concentration with galactorrhea- 
amenorrhea syndrome. They were smaller and more irregularly-shaped than those observed in normal human ${ }^{20)}$ and rat $^{93}$ pituitaries, but closely resembled the "prolactin granules" which Horvath and Kovac ${ }^{61}$ and Racadot et al. ${ }^{15)}$ described in the electron microscopy of pituitary adenomas which clinically manifested galactorrhea. It was considered that the pleomorphic granules were closely related to prolactin synthesis and release in the tumor tissue. The other granules, round ones measuring 150-300 $\mathrm{nm}$ in diameter, were especially abundant in a case (Case $\mathrm{KW}$ ) which showed high $\mathrm{HGH}$ synthesis function in spite of low plasma $\mathrm{HGH}$ concentration. Abundant cytoplasmic organelles were observed in the prolactin producing adenomas and exocytosis of secretory granules was frequently recognized. These findings were considered to represent high cellular activity of the tumor cells.

The round secretory granules measuring $150-350 \mathrm{~nm}$ in diameter were commonly observed in the tumor cells of the adenomas which showed high HGH synthesis function in the in vitro experiment and/or clinically associated with elevated plasma HGH concentration. They closely resembled the secretory granules observed in GH cell adenoma. ${ }^{1,6,15}$, Though smaller than in human anterior pituitaries, it seemed reasonable to consider that they were closely related to $\mathrm{HGH}$ synthesis and release in the adenoma tissues.

In the cytoplasm of the tumor cells from Group 3 (acromegaly group), there were round granules just mentioned as well as pleomorphic granules. The latter, which resembled but were larger and less irregularly-shaped than those in the adenomas in Group 2, were seemingly related to the prolactin synthesis and release functions of the HGH producing adenoma tissues. They closely resembled those observed by Lewis and Van Noorden ${ }^{10)}$ and Yoshida et al. ${ }^{21}$ )

Horvath and Kovac $^{6)}$ classified pituitary adenomas associated with acromegaly into 3 types. In the present series, some different ultrastructural appearances were observed. The two kinds of secretory granules were intermingled within the same tumor cells in an adenoma (Case CI) which showed high $\mathrm{HGH}$ and prolactin synthesis functions. The preoperative elevated plasma $\mathrm{HGH}$ and prolactin concentrations were markedly decreased after the tumor was totally removed. It was strongly suggested that each tumor cell would be able to produce both $\mathrm{HGH}$ and prolactin. In the other cases (Case FI and FO), the adenoma tissues were composed of intermingled polygonal cells of two types containing both granules and closely resembling "mixed adenoma" described by Horvath and Kovac, ${ }^{6)}$ Corenblum et al. ${ }^{1)}$ and Guyda et al. ${ }^{5)}$ It seemed that the two cells were respectively responsible for the high $\mathrm{HGH}$ and prolactin synthesis functions of the adenoma tissues. The adenoma tissues from the remaining cases were composed of tumor cells containing both of the granules in variable proportions. The pleomorphic granules were less irregularly-shaped than in the other tumors. No explanation could be offered concerning their functional significance, because, unfortunately, quantitative measurement of the abilities of the adenoma tissues to synthesize and release hormones was not done in these cases.

There were 2 cases in which no correlation was observed among their ultrastructures, hormone synthesis function and clinico-endocrinological features. In one (Case EF), the tumor cells contained abundant secretory granules, in spite of the low hormone synthesis function and preoperative clinical features similar to those of adenoma without recognizable functional significance. This result seemed to suggest that the adenoma, biologically divergent from normal pituitary, had elaborated substances which could be proteins differing from the normal molecules and devoid of any hormonal activity. In the other case (Case MA), the tumor cells sparsely contained only small secretory granules similar to those in Group 1, while the patient manifested galactorrhea-amenorrhea syndrome accompanied with elevated plasma prolactin concentration. It was not clear whether or not the secretory granules could be responsible for excessive prolactin production, or whether or not interfering production, release and transport of prolactin inhibitory factor (PIF) by suprasellar extension of the adenoma, could result in increased prolactin secretion from the nonneoplastic anterior pituitary. In order to explain the absence of the correlation in these cases, further study should be undertaken concerning the mechanism of protein synthesis in the adenoma cells, the chemical-immunologicalbiological properties of the protein, and the 
relationship of the hypothalamus to pituitary adenoma and surrounding anterior pituitary.

\section{Acknowledgement}

The authors are indebted to Professor Jun-ichi Kawafuchi, Chairman of Department of Neurosurgery, School of Medicine, Gunma University, for his continuous support and interest, and Drs. T. Fujii, S. Misumi and R. Sasaki, Department of Neurosurgery, Gunma University, for their excellent performances in the in vitro experiment.

\section{References}

1) Corenblum, B., Sirek, A. M. T., Horvath, E., Kovac, K. and Ezrin, C.: Human mixed somatotrophic and lactotrophic pituitary adenomas, J. Clin. Endocr. Metab. 42: 857-863, 1976.

2) Escourolle, R. and Poirier, J.: Manual of Basic Neuropathology, translated by Rubinstein, L. J., W. B. Saunders, Co., Philadelphia, London, Toronto, 1973.

3) Fukumitsu, T.: Electron microscopic study of human pituitary adenomas. Arch. Jap. Chir. 33: 329-349, 1964 (in Japanese).

4) Fujii, T., Misumi, S., Sasaki, R., Shibasaki, T. and Takeda, F.: Functional pituitary adenomas. Hormone synthesis of the adenoma tissues and result of surgical therapy. 9th Conference on Specific Topics in Neurosurgery 155-162, 1977 (in Japanese).

5) Guyda, H., Colle, E. and Hardy, J.: Histologic, ultrastructural and hormonal characterization of a pituitary tumor secreting prolactin. $J$. Clin. Endocr. Metab. 36: 531-547, 1973.

6) Horvath, E. and Kovac, K.: Ultrastructural classification of pituitary adenomas. $J$. Canad. Sci. Neurol. 3: 9-21, 1976.

7) Kageyama, N. Kobayashi, T., Yoshida, J., Asai, T., Yonezawa, T. and Tsuji, Y.: Hormone secretion from pituitary adenomas. Neurol. Surg. (Japan) 1: 295-309, 1973 (in Japanese).

8) Kuromatsu, C.: The fine structure of the human pituitary chromophobe adenoma with special reference to the classification of this tumor. Arch. Histol. Jap. 29: 41-61, 1968.
9) Kurosumi, K.; Functional classification of cell type of the anterior pituitary gland accomplished by electron microscopy. Arch. Histol. Jap. 29: 329-362, 1968.

10) Lewis, P. D. and Van Noorden, S.: "Nonfunctioning" pituitary tumors. Arch. Path. 97: 178-182, 1974.

11) Lewis, P. D. and Van Noorden, S.: Pituitary abnormalities in acromegaly. Arch. Path. 94: 119-126, 1972.

12) Luse, S.: Ultrastructural characteristics of normal and neoplastic cells. Progr. exp. Tumor Res. 2: 1-35, 1961.

13) McCormick, W. F. and Halmi, N. S. : Absence of chromophobe adenomas from a large series of pituitary tumors. Arch. Path. 92: 231-238, 1971.

14) Peake, G. T., McKeel, D. W., Jarett, L. and Daughday, W. H.: Ultrastructural, histologic and hormonal characterization of a prolactin rich human pituitary adenoma. $J$. Clin. Endocr. 29: 1383-1393, 1969.

15) Racadot, E., Vila-Porcile, L., Oliver, L. and Peillon, F.: Electron microscopy of pituitary tumours. Progr. Neurol. Surg. 6: 95-141, 1975.

16) Sasaki, R., Misumi, S., Fujii, T., Takeda, F. and Yamamoto, K.: Quantitative measurement of the ability of human chromophobe adenomas to synthesize and release human growth hormone. Neurol. Med. Chir. 15(I): 7-11, 1975.

17) Schechter, J.: Electron microscopic studies of human pituitary tumors. I. Chromophobe adenomas. Amer. J. Anat. 138: 371-386, 1973.

18) Schelin, U.: Chromophobe and acidophil adenomas of the human pituitary gland. A light and electron microscopic study. Acta Path. Microbiol. Scand., Suppl. 158, 1962.

19) Tomiyasu, U., Hirano A. and Zimmermann, H. : Fine structure of human pituitary adenoma. Arch. Path. 95: 287-292, 1973.

20) von Lawzenwitsch, I., Dickmann, G. H., Amezua, L. and Pardol, C.: Cytological and ultrastructural characterization of the human pituitary. Acta Anat. 81: 286-316, 1972.

21) Yoshida, J., Kageyama, N., Seo, H. and Kanzaki, M.: Growth hormone and prolactin secretion of pituitary adenomas. Neurol. Med. Chir. 15: 13-21, 1975. 